\title{
Effects of gamma rays on germination and growth in Jatropha curcas $\mathbf{L}$.
}

\author{
Dileswar Nayak $^{1 *}$, N. S. Patil ${ }^{2}$, L. K. Behera ${ }^{2}$ and D. B. Jadeja ${ }^{2}$ \\ ${ }^{1}$ Department of Natural Resource Management, ASPEE College of Horticulture and Forestry, Navsari Agricultural \\ University, Dandi Road, Navsari - 396450, Gujarat, INDIA \\ ${ }^{2}$ Department of Silviculture and Agroforestry, ASPEE College of Horticulture and Forestry, Navsari Agricultural \\ University, Dandi Road, Navsari - 396450, Gujarat, INDIA \\ *Corresponding author. E-mail: dileswarnayak@nau.in \\ Received: April 4, 2015; Revised received: August 30, 2015; Accepted: November 25, 2015
}

\begin{abstract}
The present investigation was carried out at the Forestry Research Farm, Navsari Agricultural University; Navsari to evaluate the gamma rays at $10 \mathrm{kR}, 20 \mathrm{kR}$ and $30 \mathrm{kR}$ induced variability in Jatropha curcas L. on germination, growth and yield for seven Jatropha genotypes (Phule J-1, Urlikanchan, Hansraj, SKN Big, Chhatrapati, Hansot and MPJ-55). The significantly maximum germination percentage $(66.96 \%)$, seedling survival $(74.18 \%)$, seedling collar diameter $(0.958 \mathrm{~cm})$, shoot length $(49.442 \mathrm{~cm})$, number of leaves per seedling $(7.757)$ and leaf area $(37.58)$ was observed in Chhatrapati genotype during nursery stage. While low rate of gamma rays treatment (10 kR) had stimulatory effect for germination percentage, seedling survival, seedling collar diameter, shoot length, number of leaves per seedling and leaf area. However, higher gamma rays doses $(30 \mathrm{kR})$ drastically reduced all studied characters. The interaction effect of genotype and gamma rays were significant for number of leaves per seedling. Further, it was not significant in other traits like germination percentage, seedling survival, seedling collar diameter, shoot length and leaf area.
\end{abstract}

Keywords: Gamma rays, Genotype, Jatropha curcas, Morphological traits

\section{INTRODUCTION}

Increasing prices of fossil fuel and diminishing resources as well as its contribution in global warming have stimulated the interest toward alternate source of energy. The solar energy is the only source for harvesting that can contribute substantially to transportation fuel needs at costs competitive with fossil fuel; is captured by photosynthesis and stored in biomass (Sommerville, 2006). The fast-growing trees allocating large quantities of carbon belowground (Christian and Ryan, 2002) as well as accumulate more carbon in plant biomass (Chen et al., 2015). These plants could be one of the best available alternative sustainable solutions to the fuel industry. Jatropha curcas L. belongs to Euphorbiaceae family has similar potential as fast growing bio-fuel crop in India. Meanwhile, currently available planting materials is lack of high yielding varieties or hybrids for oil content and yield; characterized by one or two flowering flushes with large variation for female flowers per inflorescence, capsules per plant, seeds per capsules, seed filling and oil content. Several reports suggest that very little variability of desired characters is available in natural populations of J. curcas (Divakara et al., 2010, Nayak et al., 2010 and Nayak et al., 2012); hence, it is necessary to develop variable populations artificially. In the past, the major breakthrough in castor (Family: Euphorbiaceae) improvement was achieved through mutation breeding.
Using fast neutrons, Hybrid Castor-6, a variety (Aruna) was developed with reduced plant height and earliness with increased number of spikes per plant, increased yield as compared to the parent genotype (Kulkarni and Ankineedu, 1966). In Thailand J. curcas dried seeds from the Mukkadham (Jatropha) clone were treated with ${ }^{60} \mathrm{CO}$ gamma ray doses of 0 to $20 \mathrm{kR}$ to identify the variables. In $\mathrm{M}_{3}$ generation dwarf and/or early flowering mutants of jatropha were isolated (Sakaguchi and Somabi, 1987). Pandey and Datta, 1995 reported the cotyledonary variability in J. curcas $\mathrm{L}$ using gamma radiation. In African violets (Saintpauia ionantha $\mathrm{H}$. Wendl.), gamma radiation at 15 Gy improved plant architecture of the mutants (Seneviratne and Wijesundra, 2007). Till 2000, the FAO/IAEA Mutant Varieties Database (MVD) had collected information on 2252 cultivars obtained by mutation and officially released in 59 countries worldwide including 59 mutants of oil crops. Of 1585 directly developed mutant varieties, the great majority (1411) were selected from mutated generations following the use of radiation, mainly gamma rays, as the mutagen (Maluszynski et al., 2000). Hence, mutation breeding could be one of the best available options. Looking to the above prospects and future promises, present investigation was under taken to utilize the gamma ray induced variability as a potential tool to enhance the ontogenic variations through the passage of phylogenetic variation in the improvement programme. 


\section{MATERIALS AND METHODS}

This investigation on the gamma rays induced variability in selected genotypes of $J$. curcas were conducted at Forestry Research Farm, ASPEE College of Horticulture and Forestry, Navsari Agricultural University, Navsari, Gujarat, India.

Location: The experiment was carried out at Green House Complex. Geographically, Navsari is situated at $20^{\circ} 95^{\prime}$ North latitude and $70^{\circ} 90^{\prime}$ East longitude at 10 meters above mean sea level. The experimental site is located $13 \mathrm{~km}$ away from Arabian seashore of the historical place Dandi, famous for Salt movement initiated by Father of India-The Mahatma Gandhi.

Climate and weather condition: Climatically, this region is typically tropical, characterized by fairly hot summer, moderately cold winter and more humid warm monsoon with heavy rainfall. The average annual rainfall is approximately $1355 \mathrm{~mm}$. Monsoon commences mostly from the third week of June and retreats by the end of September. Most of the precipitation is received from South West monsoon, concentrating in the month of July to August. The winter season sets in usually towards the end of October with mild cold and lasts upto February. December and January are the coldest months of the season $\left(10^{\circ}-23^{\circ} \mathrm{C}\right)$. Summer commences from mid February and lasts upto mid June. April and May are the hottest months of the year. Source of planting materials: Seven genotypes were taken for the present studies. These genotypes/ accessions were collected from different research institutes/universities across the country. The accessions Hansraj, Urlikanchan, SKN Big and SDAUJ-1 (Chhatrapati) were collected from Shardar Krishinagar Dantiwada Agricultural University, Gujarat; Phule J-1 from Mahatma Phule Krishi Vidyapeeth, Rahuri, Maharashtra and MPJ-55 from Maharana Pratap University of Agriculture and Technology, Rajasthan. One accession named Hansot was included from Navsari Agricultural University, Gujarat in the present experimentation.

Treatment with gamma rays: The dry seeds of Jatropha were irradiated in Gamma Cell-200 (Cobalt-60 source emitting 3600 rads per minute) at Nuclear Agriculture and Biotechnology Division, Bhabha Atomic Research Center, Trombay, Mumbai (Maharashtra), India. About $200 \mathrm{~g}$ jatropha seeds of uniform size/ average seed weight of each genotype in each treatment were irradiated with 10,20 and $30 \mathrm{kR}$ doses. Among them, one is control (untreated) genotype. So, there were total twenty eight treatment combinations for all seven genotypes.

Sowing of seeds in nursery: All treated seven genotypes/accessions including one control seeds were soaked in cold water for 24 hours before sowing in the 200 gauge size polythene bags filled with soil: sand: farmyard at the ratio of 1:1:1 respectively. One seed each was sown in each polythene bag. The seedlings were regularly watered with a roscan. The complete emergence of shoot above the ground was treated as germination. The germination count was recorded from 7 DAS (Days After Sowing) up to 25 DAS on a daily basis. The emergence of shoot above ground level was considered as germinated and it was converted into percentage.

Germination percentage $=$

$100 \times($ Number of seeds germinated/Number of seeds sown)

The seedlings were maintained till 150 DAS in the nursery for collecting different observations. Shoot length was measured from the collar region up to the apex of the leading shoot to the nearest $\mathrm{mm}$ at 150 DAS. The collar diameters of seedling from each treatment and replicate were measured at the collar region with the help of varnier caliper to the nearest $\mathrm{mm}$. Average values was worked out for each treatment. Area of each leaf was calculated by using leaf area meter CI-202 (CID Bioscience Inc. USA) for 10 leaves and the average leaf area was multiplied with the total number of leaves per plant and thus total leaf area was calculated and expressed in $\mathrm{cm}^{2}$. Similarly the number of leaves per seedling was counted from each treatment for all 3 replications at 150 DAS and the average number of leaves is expressed as number of leaves per seedling.

Statistical analysis: The data were statistically analyzed using Complete Randomized Design with Factorial Concept (FCRD) as suggested by Panse and Sukhatme (1967). The appropriate standard error of mean (S.Em.) and the Critical Difference (C.D.) were calculated at $5 \%$ level of probability.

\section{RESULTS AND DISCUSSION}

The large wasteland areas can be utilized by planting of Jatropha into a productive land. Several properties of the plant stemming from its hardiness, rapid growth, easy propagation and wide ranging usefulness have resulted in spread of Jatropha for beyond its original distribution. However, the full potential underlying Jatropha is far from being realized. Mutation breeding would be a valuable supplementary approach in plant breeding under situation as is prevailing in oilseeds, specifically in Physic nut, where the variability existing in natural gene pool is not enough to meet the requirements of present genetic information (Nayak, et $a l ., 2010)$. The genetic diversity in the natural population of $J$. curcas appeared narrow, since no remarkable morphological and molecular differences have been observed (Mahroliya, 2006). Mutation in tree crops is considered attractive because of lacunae in conventional breeding like time consuming, unpredictable results, long juvenile phase, high heterozygosity and fear of loss of the unique genotype (Divakara et al., 2010). Gamma radiation has been reported to have beneficial effects on many crops. In African violets (Saintpauia ionantha $\mathrm{H}$. Wendl.), gamma radiation at 15 Gy improved plant architecture of the mutants (Seneviratne and Wijesundra, 2007). The mutation on 
major gene causes distinct changes whereas, minor genes causes quantitative variation which could be realized. The combination of both types of mutations in one individual may also occur. Considering the |importance of macro and micro mutations, simultaneous utilization may prove to be better approach with breeding point of view where improvement work is at juvenile stage. Hence, to induce artificial variation, present exploration was done using gamma rays for different characters at $M_{1}$ generation among seven accessions (Hansraj, Phule J-1, Urlikanchan, SKN Big, SDAUJ-1 (Chhatrapati), Hansot, MPJ-55).

Effect of genotypes: The germination percentage was significantly influenced by genotypes. The Table 1 shows that the maximum germination percentage (66.96) was observed in genotype Chatrapati which was at par with Hansot (65.13), Hansraj (65.18), SKN Big (65.03), Phule J-1 (63.45) and MPJ 55 (64.26) genotype, while genotype Urlikanchan showed minimum germination percentage (59.61). The significantly maximum seedling collar diameter $(0.958 \mathrm{~cm})$ was recorded in Chatrapati genotype which was at par with MPJ $55(0.936 \mathrm{~cm})$ while minimum seedling collar diameter was recorded in Urlikanchan genotype $(0.904 \mathrm{~cm})$. Similarly, significantly maximum shoot length $(49.442 \mathrm{~cm})$ was recorded in Chhatrapati genotype which is at par with Phule J-1 $(49.083 \mathrm{~cm})$, Urlikanchan $(48.292 \mathrm{~cm})$, SKN Big (48.867 cm), Hansot $(48.392 \mathrm{~cm})$, MPJ $55(48.950 \mathrm{~cm})$. Also, significantly highest number of leaves per seedling (7.757) was recorded in Chhatrapati genotype. In the same way, leaf area was significantly affected due to effect of genotypes. Maximum leaf area $\left(37.58 \mathrm{~cm}^{2}\right)$ was recorded under genotype Chhatrapati. Significantly maximum seedling survival percentage (74.18) was observed under genotype Chhatrapati, while minimum survival percentage (68.48) was observed under MPJ-55 genotype. From the above results, it revealed that significant genotypic variation was observed in seed germination and seedling growth parameters (survival percentage, seedling height, collar diameter, leaves/ seedling, and leaf area). Horn and Shimelis (2013) found that the effects of different doses of gamma radiation depended also on genotypes. Dhakshanamoorthy et al. (2010) found seeds treated with 50 Gy of gamma rays revealed stimulatory effect except for germination, whereas 250 Gy dose showed inhibitory effects on traits compared to other treatments. This could be due to the damage in seed tissues and the severity of the damage depending on the dosage used. Ginwal et al., (2004) found that variance registered in $J$. curcas for seed germination, seedling growth and biomass parameters showed considerable variation among different seed sources of J. curcas. The small value of error or environmental variances of the seedling growth traits suggested that majority of characters were under genetic control. It is suggested that the plant have strong genetic control which can be exploited for improvement of this species
(Ginwal et al., 2005).

Effect of treatments :The effect of treatments on genotype is presented in table-1.The germination percentage was significantly affected by gamma radiation treatments. The results revealed that significantly maximum germination percentage was noted at $10 \mathrm{kR}$ (74.21) over no radiation treatment ( $0 \mathrm{kR})$, indicating stimulatory effects of the lower doses (Nayak et al., 2012). In other treatments germination percentage was adversely affected with the increase in the dosage of irradiation. The germination of the treated plants had shown a sharp dose rate relationship, which decreased with increase in the doses of gamma rays treatment. Percent reduction/stimulation in seed germination might have been due to the effect of mutagen on meristematic tissue of the seed (Dhakshanamoorthy et al., 2010; Dhakshanamoorthy et al., 2011). Wang et al. (2010) reported that low-dose laser irradiation induced low-frequency but significant alterations in DNA methylation level and pattern in sorghum plants. The decrease in seed germination at higher doses of the mutagen may be attributed to disturbances at cellular level caused either at physiological (or) physical level (Dwimahyani and Ishak, 2004; Pandey and Datta, 1995 and Lehtiniemi, 1977). Higher doses of gamma radiation (> $200 \mathrm{~Gy}$ ) resulted in the significant reductions in germination percentage in $J$. curcas L. (Nayak et al., 2012: Songsri et al. 2011). Also, high germination percentages $(>90 \%)$ were observed in Broccoli seeds irradiated at $<4 \mathrm{kGy}$, but the sprout length decreased with increased irradiation dose (Waje et al., 2009). However, in the present investigation lower exposure is induced seed germination. In Leucaena leucocephala exposed to a dose of $2 \mathrm{kR}$ gamma radiation increased the germination frequency in comparison to control. This may attributed to the origin of these stimulations are acceleration in cell division rates (Zaka et al., 2004) as well as activation of auxin (Gunckel and Sparrow, 1991).

Significantly highest seedling survival $(100 \%)$ was recorded in no irradiation $(0 \mathrm{kR})$ while lowest seedling survival $(50.34 \%)$ was recorded in $30 \mathrm{kR}$ treatment. The survival of $J$. curcas seedlings decreased with increasing doses of gamma rays and usually shows inhibitory effect of higher dose of gamma rays on seeds of angiosperms and gymnosperms (Akhaury and Singh, 1993; Thapa, 1999). Similar findings were reported by Ignacimuthu and Babu (1988) in Vigna mungo where plant survival decreased with increasing doses of gamma rays and EMS.

Gamma rays imposed significant impact on seedling height. The highest seedling length $(59.74 \mathrm{~cm})$ was recorded under $10 \mathrm{kR}$ which is at par with no irradiation $(58.41 \mathrm{~cm})$. It was noticed that the growth of irradiated plants were strikingly vigorous than that of control (Bandyopadhya et al., 1987). However, higher doses have inhibitory effect of mutagens on the length of seedling was evident from the decrease in length of root and shoot with increasing dose / concentration of 
gamma rays and EMS (Dhakshanamoorthy et al., 2010). Induced-dwarfism was noticed in the nursery stage when the seeds of Anacardium occidentale Cv. Madakkathata-1 were treated with gamma rays at 10, 20, 30 and $40 \mathrm{kR}$ doses using Cobalt-60 source (Mareen et al., 2008). Significant decreased in shoot length in Albizzia lebbeck was also recorded due to induced muation by Hanumatha et al., (2002). Significant decrease in shoot length in A. lebbeck was also recorded due to induced muation by Hanumatha et al., (2002).

The effect of gamma rays on seedling collar diameter was found to be significant. The significantly maximum seedling collar diameter $(0.992 \mathrm{~cm})$ was recorded over control while higher doses of gamma rays reduces seedling collar diameter. Nayak et al. (2012) reported that seedling collar diameter significantly decreased with the increased rate of gamma rays. It shows that higher exposures of gamma rays caused injury to seeds and affected seedling development. Higher doses adversely affected the seedling height and shoot length which was inversely proportional to the radiation intensity.

The gamma irradiation has significant effect on number of leaves/seedling as well as on leaf area between treatments (Table 1). The treatment $10 \mathrm{kR}$ enhanced number of leaves per seedling (7.647), which was followed by no irradiation treatment (6.701). Significantly maximum reduction in number of leaves were noted at highest gamma rays treatment i.e. $30 \mathrm{kR}$ (5.428). It suggests that low rate of gamma rays has stimulatory effects for number of leaves per seedling. But, increase in radiation intensity beyond $20 \mathrm{kR}$, adversely affected number of leaves per seedling in J. curcas (Dhakshanamoorthy et al., 2011). The increase in number of leaves might have direct contributory effects on collar diameter of seedling and origin of these stimulations, are acceleration in cell division rates (Zaka et al., 2004) as well as activation of auxin (Gunckel and Sparrow, 1991).

Leaf area is a desirable morpho-economic trait for any fast growing crop which influences on total photosynthetic space. There were significantly decreased leaf area $\left(28.95 \mathrm{~cm}^{2}\right)$ observed at higher level at $30 \mathrm{kR}$ treatment, however low doses at $10 \mathrm{kR}$ increases leaf area $\left(42.28 \mathrm{~cm}^{2}\right)$. The present findings are supported by Rafiullah and Hasan (1994) who reported gradual decrease in leaf area in Brassica species with the increase intensities of radiation. Generally, 10 krads dose produced a stimulatory effect in most of the characters while $25 \mathrm{krads}$ decreased in brassica. Ramesh et al., (2012) reported that significantly decreased in leaf area of mulberry when treated at $10 \mathrm{kR}$ using gamma rays where as low doses (1 $\mathrm{kR})$ showed slightly bigger leaf area as compared to control. Similar results on growth parameters have been reported in A. lebbeck by Singh and Paliwal (1987). Gamma rays irradiation with the dose of $10 \mathrm{~Gy}$ found desirable genetic variability on plant development of $J$. curcas (Dwimahyani and Ishak, 2004). Pandey and Datta (1995) reported that higher doses of gamma rays have strong variation on size, shape and stomata number in $J$. curcas. In soybean plant leaves developed from gamma irradiated seeds showed reductions in stomatal density and stomatal number compared to the control plants (Celik et al., 2014). However, in Emblica officinalis grafts; the leaf area showed inconsistent relationship between the dosage of gamma rays and genetic variability which indicates a better scope for success in further improvement of desirable traits in the existing commercial variety of the crop (Selvi et al. 2007).

Effect of interaction: The interaction of genotypes and gamma rays treatments were found non-significant in influencing on germination percentage, shoot length,

Table 1. Effect of gamma rays on germination and seedling survival percentage of J. curcas .

\begin{tabular}{|c|c|c|c|c|c|c|}
\hline Treatments & $\begin{array}{l}\text { Germination } \\
\text { percentage }\end{array}$ & $\begin{array}{l}\text { Survival } \\
\text { percentage }\end{array}$ & $\begin{array}{l}\text { Seedling collar } \\
\text { diameter }(\mathbf{c m})\end{array}$ & $\begin{array}{l}\text { Shoot length } \\
(\mathrm{cm})\end{array}$ & $\begin{array}{l}\text { Number of } \\
\text { leaves/ } \\
\text { seedling }\end{array}$ & $\begin{array}{l}\text { Leaf area } \\
\left(\mathrm{cm}^{2}\right)\end{array}$ \\
\hline \multicolumn{7}{|l|}{ Genotypes (G) } \\
\hline G1: Phule J-1 & 63.45 & 71.74 & 0.913 & 49.083 & 6.047 & 36.85 \\
\hline G2: Urlikanchan & 59.61 & 71.43 & 0.904 & 48.292 & 6.500 & 36.68 \\
\hline G3: Hansraj & 65.18 & 71.24 & 0.930 & 45.467 & 6.107 & 36.40 \\
\hline G4: SKN Big & 65.03 & 71.72 & 0.927 & 48.867 & 6.292 & 35.25 \\
\hline G5: Chhatrapati & 66.96 & 74.18 & 0.958 & 49.442 & 7.757 & 37.58 \\
\hline G6: Hansot & 65.13 & 73.61 & 0.934 & 48.392 & 6.747 & 35.51 \\
\hline G7: MPJ 55 & 64.26 & 68.48 & 0.936 & 48.950 & 6.278 & 35.45 \\
\hline S. Em. + & 1.21 & 0.99 & 0.008 & 0.694 & 0.100 & 0.15 \\
\hline C. D. at $5 \%$ & 3.51 & 2.80 & 0.023 & 2.010 & 0.289 & 0.433 \\
\hline \multicolumn{7}{|l|}{ Irradiation (I) } \\
\hline I0: No irradiation & 71.78 & 100.00 & 0.992 & 58.41 & 6.701 & 40.98 \\
\hline I1: $10 \mathrm{kR}$ & 74.21 & 74.49 & 0.947 & 59.74 & 7.647 & 42.28 \\
\hline I2: $20 \mathrm{kR}$ & 61.07 & 62.26 & 0.914 & 44.97 & 6.355 & 32.76 \\
\hline I3: $30 \mathrm{kR}$ & 49.87 & 50.34 & 0.861 & 30.30 & 5.426 & 28.95 \\
\hline S. Em. + & 00.90 & 00.75 & 0.006 & 0.525 & 0.075 & 0.085 \\
\hline C. D. at $5 \%$ & 02.60 & 2.12 & 0.018 & 1.520 & 0.218 & 0.247 \\
\hline \multicolumn{7}{|l|}{ Interaction ( $\mathbf{G}$ x I) } \\
\hline S. Em. + & 2.37 & 0.75 & 0.016 & 0.439 & 0.199 & 0.60 \\
\hline C. D. at $5 \%$ & NS & NS & NS & NS & 0.578 & NS \\
\hline C. V. $\%$ & 6.39 & 4.77 & 3.009 & 4.97 & 5.287 & 4.94 \\
\hline
\end{tabular}


Table 2. Interaction effect of gamma rays on number of leaves per seedling in J. curcas .

\begin{tabular}{|c|c|c|c|c|c|}
\hline \multirow{2}{*}{$\begin{array}{c}\text { Interaction effects } \\
\text { ( Genotype X Irradiation ) }\end{array}$} & \multicolumn{5}{|c|}{ Number of leaves/seedling } \\
\hline & $I_{0}: 0$ kR & $I_{1}: 10 \mathrm{kR}$ & $\mathrm{I}_{2}: 20 \mathrm{kR}$ & $I_{3}: 30 \mathrm{kR}$ & Mean \\
\hline G1: Phule J -1 & 5.863 & 7.623 & 5.580 & 5.120 & 6.047 \\
\hline G2: Urlikanchan & 6.743 & 7.753 & 6.393 & 5.110 & 6.500 \\
\hline G3: Hansraj & 6.367 & 7.093 & 5.847 & 5.120 & 6.107 \\
\hline G4: SKN Big & 5.880 & 7.933 & 6.240 & 5.113 & 6.292 \\
\hline G5: Chhatrapati & 8.070 & 8.343 & 7.797 & 6.817 & 7.757 \\
\hline G6: Hansot & 7.353 & 7.827 & 6.123 & 5.684 & 6.747 \\
\hline G7: MPJ 55 & 6.633 & 6.957 & 6.503 & 5.017 & 6.278 \\
\hline Mean & 6.701 & 7.647 & 6.355 & 5.426 & \\
\hline Source & S. Em. \pm & & C.D. at $5 \%$ & & \\
\hline G & 0.100 & & 0.289 & & \\
\hline I & 0.075 & & 0.218 & & \\
\hline G x I & 0.199 & & 0.578 & & \\
\hline
\end{tabular}

G: Genotye, I: Irradiation

seedling collar diameter and leaf area (Table 2). However, significant variations of number of leaves due to variety and different treatments with their interactions were noticed. Chatrapati accession significantly enhanced mean number of leaves (8.343) was noted under $10 \mathrm{kR}$ gamma rays treatment, which was followed by $0 \mathrm{kR}(8.24)$. Minimum number of leaves per seedling (5.017) was recorded in $30 \mathrm{kR}$ treatment under MPJ 55 genotype. The low rate of gamma rays has stimulatory effects for number of leaves per seedling. The biological effect of gamma-rays is based on the interaction with atoms or molecules in the cell. The low radiation dose used could have produced its long-term effects in part by means of the stimulation of lipid degradation, possibly mediated through the action of free radicals that are known to be generated after irradiation (Katsaras et al., 1986; Voisine et al., 1991). The stimulating effects of gamma ray on germination may be attributed to the activation of RNA synthesis (Kuzin et al., 1975) on coster bean, or protein synthesis (Kuzin et al., 1976) which occurred during the early stage of germination after seeds irradiated with $4 \mathrm{~K}$-rad. Hence, these interaction factors may be responsible for the contribution of total number of leaves in the seedlings.

\section{Conclusion}

The significantly maximum germination percentage, seedling survival, seedling collar diameter, shoots length, number of leaves per seedling and leaf area was observed in Chhatrapati genotype during nursery stage. The low rate of gamma rays treatment $(10 \mathrm{kR})$ has stimulatory effect; however higher gamma rays doses drastically reduced seedling germination, seedling survival, seedling collar diameter, shoot length, number of leaves per seedling and leaf area. The interaction effect of genotype and gamma rays were significant for number of leaves per seedling. While, it was not significant in other traits like germination percentage, seedling survival, seedling collar diameter, shoot length and leaf area. The present study on induced variability of $J$. curcas by gamma rays with respect to germination percentage, seedling survival, seedling collar diameter, shoots length, number of leaves per seedling, leaf area were maximum in Chhatrapati genotype during the germination and seedling growth stage. The application of $10 \mathrm{kR}$ gamma rays radiation had stimulatory effect which may be best for producing wide desired variant in Jatropha crop improvement.

\section{ACKNOWLEDGEMENTS}

I am gratefully acknowledging University Grant Commission, New Delhi for financial support in the form of RG National Fellowship \{No.14-2(ST)/2008(SA), Dt.31.09.2009\} during Ph.D. degree.

\section{REFERENCES}

Akhaury, K.D.N. and Singh, A.K. (1993). Effect of Gamma rays on the seed output of Vicia species. Neo Botanica, 1(1 -2): 63-67.

Bandyopadhya, Bandana; Mallik, R. and Chattarjee, A.K. (1987). Effect of gamma irradiation on growth and biomass yield of Leucaena leucocephala (L.) DEWIT. Indian Forester, 113(7): 484-489.

Celik, O.; Cimen, A. and Zekiye, S. (2014). Response of soybean plants to gamma radiation: Biochemical analyses and expression patterns of trichome development. Plant Omics Journal, 7(5): 382-391.

Chen, Yuanqi; Zhanfeng Liu; Xingquan Rao; Xiaoling Wang; Chenfei Liang; Yongbiao Lin; Lixia Zhou; Xi-an Cai and Shenglei, Fu. (2015). Carbon storage and allocation pattern in plant biomass among different forest plantation stands in Guangdong, China. Forest, 6: 794808.

Christian, P. Giardina and Michael, G. Ryan (2002). Total belowground carbon allocation in fast-growing Eucalyptus plantation estimated using a carbon balance method. Ecosystem, 5: 487-499.

Dhakshanamoorthy, D.; Selvaraj, R. and Chidambaram, A. (2010). Physical and chemical mutagens in Jatropha curcas L. to induce variability in seed germination, growth 
and yield traits. Romanian Journal of Biology, 55 (2): 113125.

Dhakshanamoorthy, D.; Radhakrishnan, S. and Chidambaram, A.L.A. (2011). Induced mutagenesis in Jatropha curcas L. using gamma rays and detection of DNA polymorphism through RAPD marker. Comptes Rendus Biologies 334 (1): 24-30.

Divakara, B.N.; Upadhyaya, H.D.; Wani, S.P. and Gowda, C.L. Laxmipathi (2010). Biology and genetic improvement of Jatropha curcas L.: A review. Applied Energy, 87: 732742.

Dwimahyani, Ita and Ishak (2004). Induced mutation on Jatropha (Jatropha curcas L.) for improvement of agronomic characters variability. Atom Indonesia, 30 (2): 54-59.

Ginwal, H.S.; Phartyal, S.S.; Rawat, P.S. and Srivastava, R.L. (2005). Seed source variation in morphology, germination and seedling growth of Jatropha curcas Linn. in Central India. Silvae Genetica, 54: 76-80.

Ginwal, H.S.; Rawat, P.S. and Srivastava, R.L. (2004). Seed source variation in growth performance and oil yield of Jatropha curcas Linn. in Central India. Silvae Genetica, 53: $186-192$.

Gunckel, J.E. and Sparrow, A.H. (1991). Ionizing radiation: biochemical, physiological and morphological aspects of their effects on plants, In: W. Ruland (Ed.), Plant Physiology XVI, Spring Verlag, Berlin, pp. 555-611.

Hanumatha, M.; Vasudev, R. and Shashidhara, G.B. (2002). Effect of gamma irradiation and pre-sowing treatments on growth attributes of Albizzia lebbeck (L.) Benth. Indian Journal of Forestry, 25(2): 136-138.

Horn, L. and Shimelis, H. (2013). Radio-sensitivity of selected cowpea (Vigna unguiculata) genotypes to varying gamma irradiation doses. Scientific Research and Essays, 8(40): 1991- 1997.

Ignacimuthu, S. and Babu, C.R. (1988). Radiosensitivity of the wild and cultivated urd and mungbean. Indian Journal of Genetics, 48(3): 331-342.

Katsaras, J.; Stinson R.H.; Kendal E.J. and McKersie B.D. (1986). Structural simulation of free radical damage in amodelmembrane system: a smallangle X-ray diffraction study. Biochimica Biophysica Acta 861: 243- 250.

Kulkarni, L.G. and Ankineedu, G. (1966). Isolation of pistillate lines in castor for exploitation of hybrid vigour. Indian Journal of Genetics and Plant Breeding, 26: 363-366.

Kuzin, A.M.; Vagabova, M.E. and Prinak-Mirolyubov, V.N. (1975). Molecular mechanisms of the stimulating effect of ionizing radiation on seed. Activation of RNA synthesis. Radiobiologiya., 15: 747-750.

Kuzin, A.M.; Vagabova, M.E. and Revin, A.F. (1976). Molecular mechanisms of the stimulating action of ionizing radiation on seeds. 2. Activation of protein and high molecular RNA synthesis. Radiobiologiya, 16: 259- 261.

Lehtiniemi, T. (1977). Factor affecting gamma radiation sensitivity of Scots pine and Norway spruce seeds. Sylva Fennica, 11(1): 69-80.

Mahroliya, Naveen (2006). Molecular diversity analysis of Jatropha germplasm, Thesis Submitted to JNKVV, Jabalpur, India.

Maluszynski, M.; Nichterlein, K.; Van, Zanten L. and Ahloowalia, B.S. (2000). Officially released mutant varieties the FAO/IAEA Database. Mutation Breeding Reviews, 12:1-84.

Mareen, A.; Mahapatro, G.K. and Mathew, J. (2008). Variability in Cashew (Anacardium occidentale) by induced irradiation. Indian Journal of Agricultural Sciences, 78(3): 230-233.

Nayak, D.; Behera, L.K. and Jadeja, D.B. (2010). Genetic diversity among different seed sources of Jatropha curcas Linn. Green Farming 3 (1): 16-19.

Nayak, D.; N.S. Patil; S.K. Jha and D.B. Jadeja (2012). Gamma rays induced variability in Jatropha curcas L. Phytotechnology: Emerging Trends, Scientific Publishes, India, pp. 248-251.

Pandey, R.K. and Datta, S.K. (1995). Gamma ray induced cotyledonary variabilities in Jatropha curcas L. Journal of Nuclear Agriculture and Biology, 24(1): 62-66.

Panse, V.G. and Sukhatme, P.V. (1967). Statistical methods for agricultural workers. Indian Council of Agricultural Research, New Delhi, pp 21.

Rafiullah, S. and Hasan, S. (1994). Effect of gamma irradiation on morphology of Brassica species. Sarhad Journal of Agriculture, 10 (2): 169-174.

Ramesh, H. L.; Murthy, V. N. Yogananda and Munirajappa (2012). Effect of different doses of gamma radiation on growth parameters of Mulberry (Morus) variety Kosen. Journal of Applied and Natural Science 4 (1): 10-15.

Sakaguchi, S. and Somabi, M. (1987). Exploitation of promising crops of Northeast Thailand, Siriphan Offset, Khon Kaen, Thailand. pp. 50.

Selvi, B.S.; Ponnuswami, V. and Sumathi, T. (2007). Genetic variability studies in gamma ray induced Amla (Emblica Officinalis Gaertn.) grafts. Journal of Applied Sciences Research, 3 (12): 1929-1932.

Senevirante, K.A.C.N. and Wijesundra, D.S.A. (2007). First African Violets (Saintpauia ionantha H. Wendl.) with a changing colour pattern induced by mutation. American Journal of Plant Physiology, 2: 233-236.

Singh, S.S. and Paliwal, G.S. (1987). Sensitivity of Albizzia lebbek seeds to gamma rays. Indian Forester, 113 (7): 490-500.

Sommerville, C. (2006). The billion-ton biofuels vision. Science, 312: 1227.

Songsri, P.; Suriharn, B.; Sanitchon, J.; Srisawangwong, S. and Kesmala, T. (2011). Effects of gamma radiation on germination and growth characteristics of Physicnut (Jatropha curcas L.). Journal of Biological Sciences, 1: 1 - 3.

Thapa, C.B. (1999). Effect of acute exposure of gamma rays on seed germination of Pinus kesiya Gord and P. wallichiana A.B. Jacks. Botanica Orientalis Journal of Plant Science. pp. 120-121.

Voisine, R.; V'ezina, L.P. and Willemont, C. (1991). Induction of senescence like deterioration of micro small membranes from cauliflower by free radicals generated during gamma irradiation. Plant Physiology, 97: 545- 550.

Waje, C.K.; Jun SoYun; Lee, Yeon Kyung; Moon, Kwang Deog; Hee, Choi-Yong and Ho, Kwon Joong (2009). Seed viability and functional properties of broccoli sprouts during germination and postharvest storage as affected by irradiation of seeds. Journal of Food Science, 74(5): 370-374.

Zaka, R.; Chenal, C. and Misset, M.T. (2004). Effect of low doses of short-term gamma radiation on growth and 